János Kundrák, Viktor Molnár, Miskolc, Hungary, Angelos P. Markopoulos, Athens, Greece

\title{
JOINT MACHINING: HARD TURNING AND GRINDING
}

\begin{abstract}
The manufacturing of increasingly complex components and, at the same time, production of parts of superior quality is a growing trend in industry today. This tendency is realized through advanced machining processes that take advantage of the capabilities of the new machine tools, the properties of cutting tools and the advancements in control and CAD/CAM/CAE systems available today. However, productivity is important and it is not always possible to reduce machining times, while difficult-to-cut materials, successive processes and tool replacements hinder the desired goal. However, ready-machining of the components is a feasible way to achieve the aforementioned requirements. A possibility for this is machining the workpieces on one machine tool, with only one clamping. The fulfilment of the processing and finishing of parts with one clamping and the application of several processes, i.e. hard turning and grinding, in one machine tool is called joint or combined machining. There are several advantages to this arrangement in manufacturing processes, which are discussed in this paper.
\end{abstract}

Keywords: hard turning; grinding; hybrid machining; machining efficiency; surface roughness; roundness; cylindricity.

\section{INTRODUCTION}

The idea behind joint machining involves the integration of hard turning and grinding. Hard turning is characterized by efficient material removal and flexibility, while grinding can offer unsurpassed surface quality to the finished product. The concept lies in exploiting, on one hand, the high material removal ability and the flexibility of hard turning and, on the other, the advantages of the reliability and the high quality of grinding. Other manufacturing processes such as boring or honing can be included in the scheme [1]. However, in order to have a beneficial set-up, all this has to be carried out with only one clamping of the workpiece.

Grinding has been the finishing process for almost all high-end industrial products for a long time; the finishing of hardened materials implied exclusive use of grinding wheels, as there were no other cutting tools suitable for such a task. However, some grinding processes, e.g. internal grinding, can be very slow, due to the allowance in the range of $\mu \mathrm{m}$ that is to be removed at each pass. As an alternative, boring can perform the same task faster. In order to attain the same quality requirements, however, new materials for cutting tools had to be developed. The main developments in cutting technology include coated tool materials that offer the opportunity to fine tune the cutting tool to the material being machined and superhard cutting tool materials that are suitable for cutting components of the highest hardness. 
Furthermore, machining accuracies down to $10 \mu \mathrm{m}$ can now be achieved for conventional cutting processes and dry or near dry cutting is finding widespread application $[2,3,4]$.

Indeed, new advanced hard tools, such as cubic boron nitride (CBN), reached the phase of industrial application at the end of the previous century. Since then, many improvements on these materials and tools with CBN have been introduced and productivity of the processes has dramatically increased - by four to five times or even higher - maintaining at the same time the accuracy and surface quality in terms of surface roughness obtained by grinding. Among the advantages of hard turning are higher rigidity, high thermal stability, minimal use of cutting fluids and quick workpiece clamping.

Nevertheless, the complete substitution of grinding with hard turning is not without problems. First of all, turning operations leave a distinct pattern of cutting marks on the finished workpiece; a thread-like regularly repeating line that creates a non-desired topography on the surface. This periodic topography, depending on the feed and depth-of-cut applied in the process, can be at the microscopic scale and invisible to naked eye, but it is disadvantageous where sealing surfaces, connecting surfaces and fixed junctions are involved [5]. In grinding, however, a random topography is created, due to the cutting action of the grains on the grinding wheels, and the problem is diminished. Although the two manufacturing processes can provide the same roughness, the functionality of the finished surface is different in each case. Another problem that hinders the substitution of grinding with hard turning is connected to tool life. The wear of CBN inserts is difficult to assess and depends on many factors. There are several studies that are connected with this issue, see [6]; however, it can be stated that the process safety of hard turning, in terms of accurately predicting $\mathrm{CBN}$ insert wear, is worse than that of grinding.

The advantage of changing from manufacturing on different machine tools to joint machining is without doubt the remarkable reduction in the lead time and the drastic shortening of the production chain. In cylindrical components or shapes of bodies of revolution, the clamping errors from consecutive centring are completely eliminated; thus, axisymmetric bodies, for instance, can be processed with different processes, with the same defining position, without the possibility of clamping errors. Furthermore, errors from repeated clamping and errors from positioning the distance measuring systems after each clamping are also removed [7].

\section{FEASIBILITY OF HARD CUTTING REPLACING GRINDING}

In industry today, one can often encounter the machining of hardened surfaces. In general, in order to improve the reliability of products, the durability of parts must be also increased. The latter can be accomplished either by the 
formation of ever harder surfaces and/or a higher number of hard surfaces. Due to the fact that finish machining is connected to high costs, making machining more economical is associated with improvement of the technological parameters, i.e. tools and machine tools, the techniques of finish machining, and the reduction of the amount of machining time and number of processes. Grinding is a wellestablished and theoretically supported manufacturing process; therefore, replacement it requires careful examination. Several significant factors strongly connected to the performance of the process need to be examined: quality, flexibility, economy and ecology. A prominent trend in investigations is the examination of the cutting capability of hardened steels with hard tools. In Figure 1 an overview of hard-turning performance in connection to IT (ISO tolerance) and roughness (values of $\mathrm{Rz}$ ) is presented [8]. The trend is moving towards lower $\mathrm{Rz}$ values and more demanding ISO classes; it is now possible to obtain IT3 at Rz values below $1 \mu \mathrm{m}$.

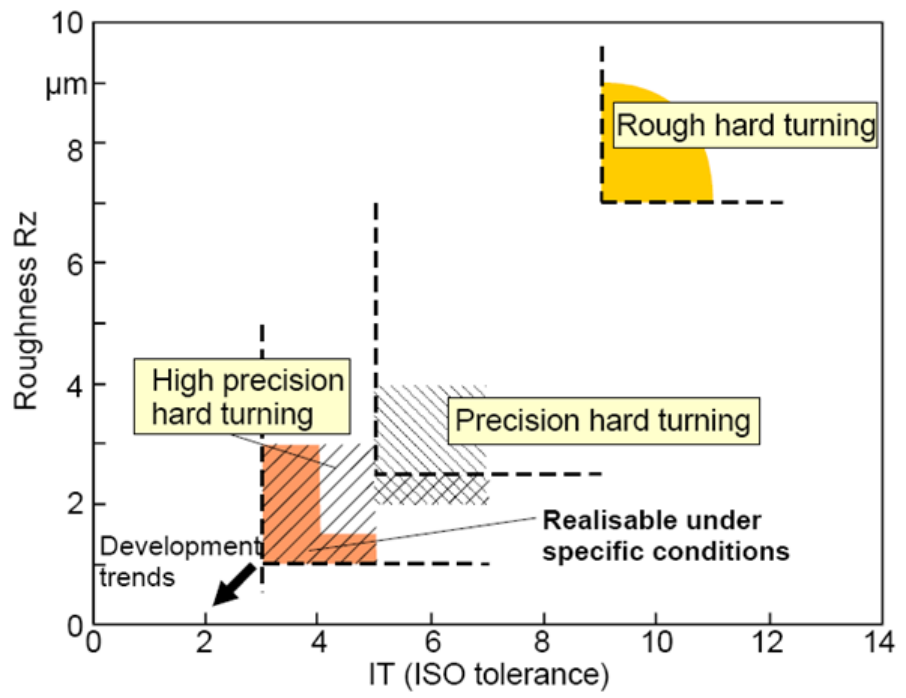

Figure 1 - Roughness Rz versus IT class in hard turning [6]

In previous works the authors have carried out experimental and theoretical research the comparing hard boring and internal grinding [9, 10]. The results clearly exhibit that hard boring can be applied for precision machining of internal cylindrical surfaces, i.e. bore holes, offering important advantages in the machining 
of parts with the examined geometry. Hard cutting is a suitable alternative to grinding operations, when economy, ecology, flexibility and quality are considered.

Regarding the economic aspects of the operation, material removal and surface rate in bore machining is better when applying hard turning than grinding; in hard boring the machining times decrease significantly in the case of the disctype parts with a bore hole examined so far [9]. From an environmental point of view, hard cutting is more advantageous compared to grinding, as no cutting fluid is required [10]. One of the main benefits of hard turning over grinding is its high flexibility and the ability to machine complex workpiece geometry at one setting. This is true especially in the machining of parts that have many short surfaces of various forms and where both external and internal surfaces are to be machined. In the case of bore holes, where the plane and cone surfaces of the gears are to be machined, the advantages of hard turning continue to increase. Finally, the specified accuracy and roughness requirements for the parts' surfaces can be achieved through hard turning.

When machining with a single point tool, tool wear may cause problems affecting stability of the process, accuracy and rigidity. Moreover, process kinematics create scroll-forming on the machined surface, which needs to be eliminated for certain applications; in these cases the application of grinding is unavoidable. Of course, by modifying the turning kinematics, the periodical topography of the surface can be altered. However, this only partially resolves the problem [11].

\section{APPLICATION OF JOINT MACHINING}

As hard turning and grinding have certain advantages and disadvantages, a suitable combination of them allows most of the disadvantages to be avoided [12]. By application of joint machining, supplementary times decrease, machining efficiency increases and surface quality improves. In order to demonstrate these benefits an experimental study with three different machining strategies is carried out and the results are analysed. As a case study, the machining of a gear wheel is selected. The first strategy (Fig. 2a) is hard turning of the face and bore; the second (Fig. 2b) is bore grinding; and the third (Fig. 2c) is the combination of these: hard turning of the face, bore and cone, then bore and cone grinding, with all activities carried out in a single clamping.

In the third version, the workpiece is machined in one clamping on one machine tool, namely EMAG VSC 400 DDS; the aim is not to replace one process by another but for them to complement each other in an optimal way. To ensure the prescribed topography of the finished surface and exploit the high capacity of material removal achieved by hard turning, grinding is performed after hard turning. In other words, a traditional machining chain is applied. This way 
transportation, storage and clamping time are dramatically reduced, positioning errors are diminished and coolant is applied only at the grinding stage, thus it is minimized. Performing the two processes on one machine tool and in one clamping reduces grinding allowance to its minimum, which is significant, especially in grinding high length bores.

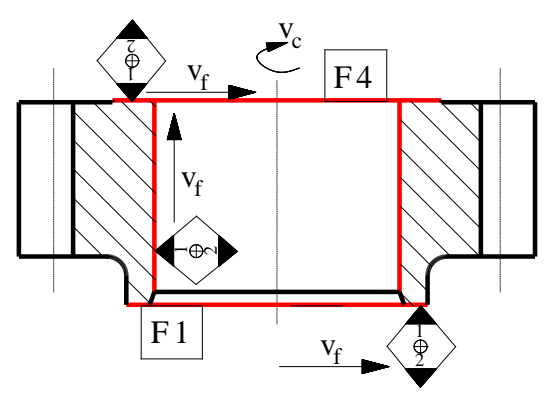

(a)

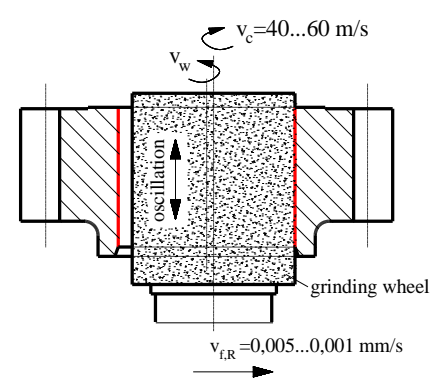

(b)

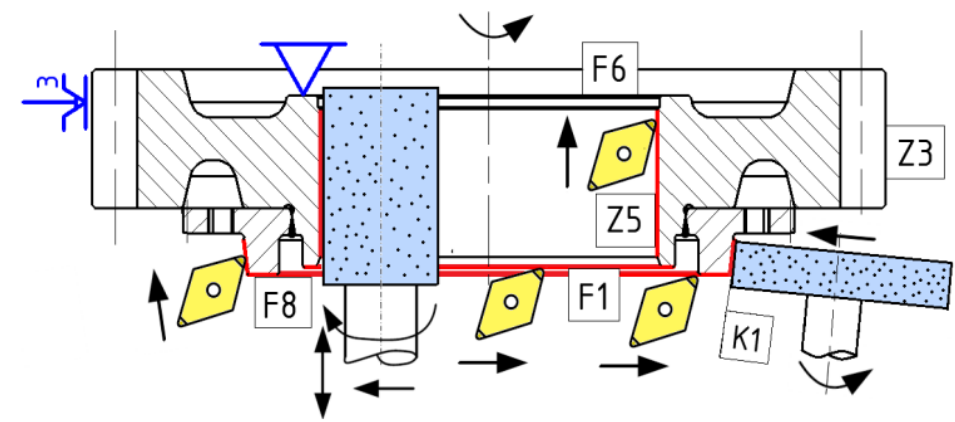

(c)

Figure 2 - Material removal by (a) hard turning, (b) grinding and (c) joint machining

\section{RESULTS AND DISCUSSION}

After applying the three different machining strategies the geometrical accuracy of the bores of the gears was measured. After finishing, it was found that joint machining provides tolerance IT5, as can be seen in Figure 3.

In Figure 3 roundness and cylindricity are compared. In addition, the micro profiles of the three machined surfaces were analyzed. The Abbott-Firestone curves were plotted; from their agreement of their shape with the shape of the normal distribution function, conclusions can be drawn about the randomness of 
the topography (Fig. 4). The joint procedure was found to be the closest of the three. That is why it can be stated that the topography of the surface machined by the joint procedure was proved to best fit to the working specifications for the machined surface in this comparison.

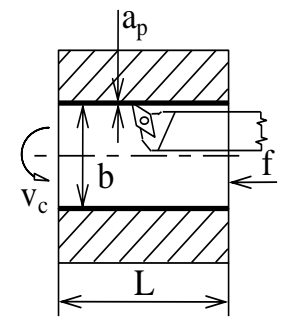

Roundness

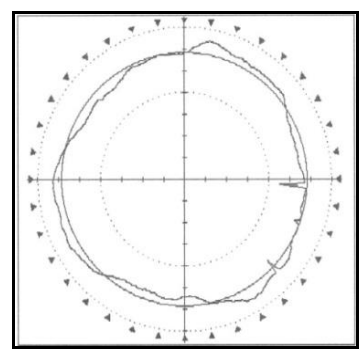

Hard turning

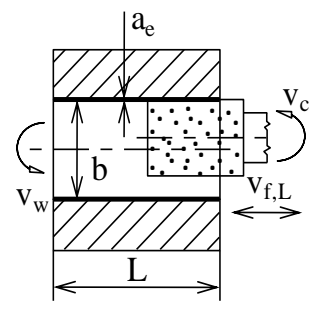

Grinding

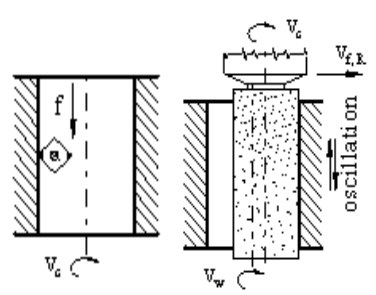

Joint machining
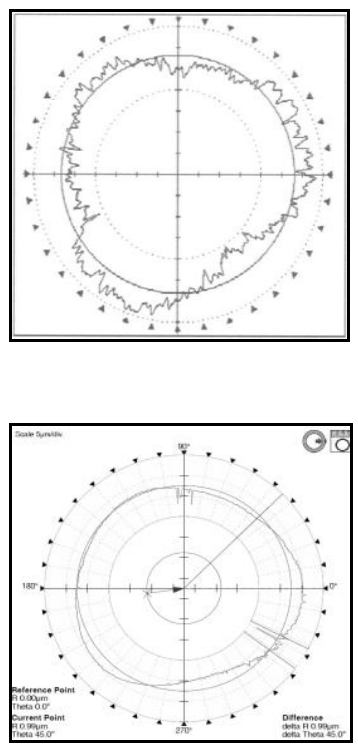

Cylindricity

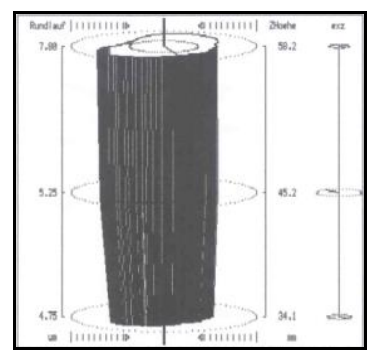

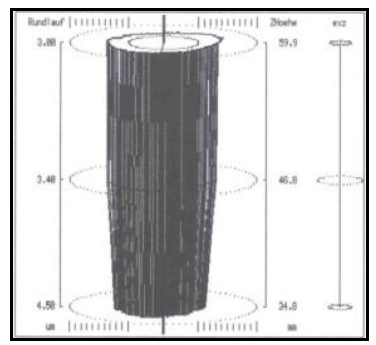

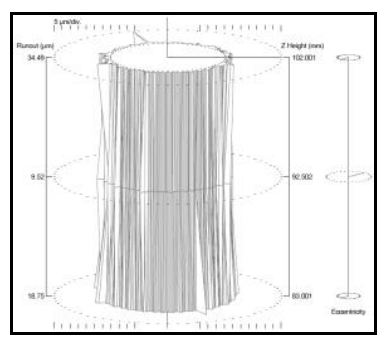

Figure 3 - Roundness and cylindricity measured for the three different cases 


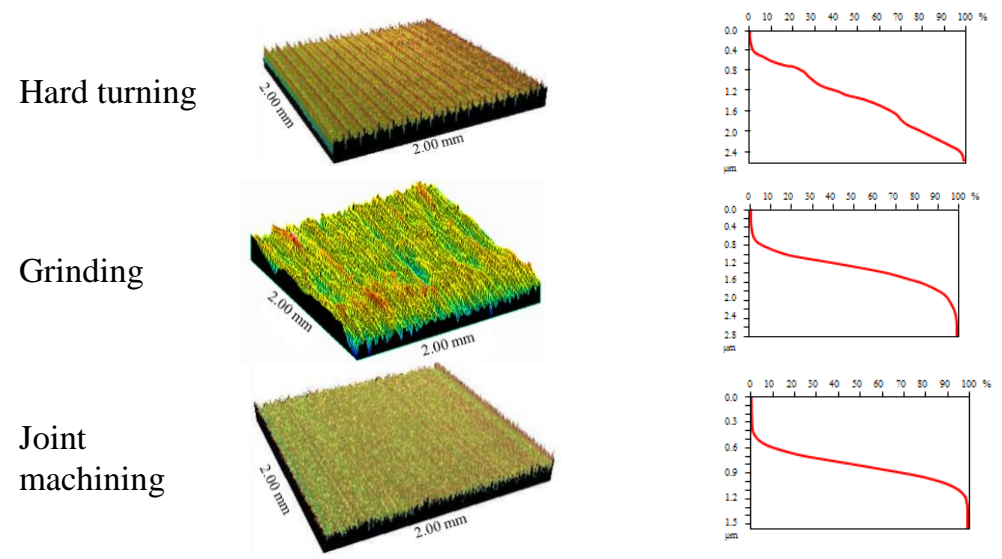

Figure $4-3 D$ topography of finished surfaces

\section{SUMMARY}

In this paper, advantages and disadvantages of removing material from metallic parts by hard turning or by grinding were studied. A third alternative was also examined: joint machining, namely the removal of bulk material with hard turning and finishing with grinding, with one clamping of the workpiece. A comparative analysis of the three procedures was carried out in a case study, analysing the accuracy and 3D surface roughness of the machine surfacesto identify the random features of the topography. It was concluded that joint machining can achieve the same levels of accuracy as grinding and at the same time provide a surface topography of the finished workpieces that meets the working specifications.

\section{ACKNOWLEDGEMENTS}

Project No. NKFI-125117 has been implemented with the support provided from the National Research, Development and Innovation Fund of Hungary, financed under the K_17 funding scheme. The described study was carried out as part of the EFOP-3.6.1-16-00011 "Younger and Renewing University - Innovative Knowledge City - institutional development of the University of Miskolc aiming at intelligent specialisation" project implemented in the framework of the Szechenyi 2020 program. Both sources of funding are gratefully acknowledged.

References: 1. Lütjens, P.: Große Vorteile durch Kombinationsbearbeitung. Werkstatt und Betrieb 9, 2008, pp.114-120. 2. Weinert, K., Inasaki, I., Sutherland, J.W., Wakabayashi, T.: Dry Machining and Minimum Quantity Lubrication. CIRP Annals 53(2), 2004, pp. 511-537. 3. Varga, G.: Investigation of 3D Surface Roughness on Environmentally Friendly Way Milled Surfaces, Rezanie i Instrumenty v 
Tekhnologicheskih Sistemah 81 2012, pp. 24-33. 4. Varga, G., Szigeti, F., Dezsö, G.: 3D Surface Topography Analysis of Environmentally Consciously Drilled Holes, Annals of Faculty of Engineering Hunedoara - International Journal of Engineering XI(3), 2013, pp. 99-104. 5. Kundrák, J., Gyáni, K., Felhö, C., Markopoulos, A.P., Deszpoth, I.: Analysis of lead twist in modern high-performance grinding methods. IOP Conference Series: Materials Science and Engineering 161, 2016, 012005. 6. Kundrák, J., Markopoulos, A.P., Makkai, T.: Assessment of tool life and wear intensity of CBN tools in hard cutting. Key Engineering Materials 686, 2016, pp. 1-6. 7. Karpuschewski, B., Wehmeier, M., Inasaki, I.: Grinding Monitoring System Based on Power and Acoustic Emission Sensors. CIRP Annals 49(1), 2000, pp. 235-240. 8. Byrne, G., Dornfeld, D., Denkena, B.: Advancing Cutting Technology. CIRP Annals 52(2), 2003, pp. 483-507. 9. Kundrák, J., Mamalis, A.G., Markopoulos, A.: Finishing of Hardened Boreholes: Grinding or Hard Cutting? Materials and Manufacturing Processes 19(6), 2004, pp. 979-993. 10. Kundrák, J., Mamalis, A.G., Gyani, K., Markopoulos, A.: Environmentally Friendly Precision Machining. Materials and Manufacturing Processes 21(1), 2006, pp. 29-37. 11. Sztankovics, I., Kundrák, J.: The characteristic parameters of the twist structure on cylindrical surfaces machined by turning procedures. Applied Mechanics and Materials 693, 2014, pp. 418-423. 12. Moriwaki, T.: Multifunctional machine tool. CIRP Annals 57(2), 2008, pp. 736-749.

\title{
Янош Кундрак, Віктор Мольнар, Мішкольц, Угорщина, Ангелос Р. Маркопулос, Афіни, Греція
}

\section{ПОСДНАНА ОБРОБКА: ЧИСТОВЕ ТОЧІННЯ ТА ШЛІШУВАННЯ}

\begin{abstract}
Анотація. Виробництво все більш складних компонентів $i$, в той же час, виробництво деталей вищої якості - зростаюча тенденція в галузі. Ця тенденція реалізується завдяки успішному процесу обробки, що використовуе можливості нового устаткування, властивостей інструментів і досягнень в області управління а також CAD / CAM / CAE, доступних сьогодні. Однак продуктивність важлива, $і$ не завжди можливо скоротити час обробки, а саме такі фактори, як важкооброблювані матеріали, деякі послідовні проиеси та зміни інструменту, заважають досягненню бажаних результатів. Однак спільна механічна обробка компонентів $\epsilon$ можливим способом досягнення вище вказаних вимог. Для иього існує можливість обробки заготовок на одному верстаті з однієї установки. Виконання чорнової $і$ чистової обробки деталей з одним зажимом і застосування декількох прочесів, тобто точної токарної обробки $i$ шліфування на одному верстаті, яке називається спільною або комбінованою обробкою. $Є$ кілька переваг иієї спільності в виробничих прочесах, які і обговорюються в чій статті. У иььому дослідженні були вивчені переваги $і$ недоліки видалення матеріалу з металевих заготовок иляхом точіння або шліфування. Було також розглянуто третій варіант: поєднана механічна обробка, а саме видалення оброблюваного матеріалу за допомогою точного точіння $і$ чистове шліфування з однісї установки заготовки. Порівняльний аналіз трьох процедур був проведений в тематичному дослідженні, аналізуючи точність і тривимірну шорсткість обробленої поверхні, щзоб виявити випадкові особливості топографії. Був зроблений висновок, щэо поєднана обробка може досягати тих же рівнів точності, щуо і окремо шліфування, $і$ в той же час забезпечувати мікрорельєф поверхні готових деталей, який відповідає робочим вимогам.
\end{abstract}

Ключові слова: чистове точіння; иліфування; гібридна обробка; ефективність обробки; шорсткість поверхні; округлість; ичиліндричність. 